\title{
Use of baobab pulp as a source of vitamin $C$ in the diet of Nile tilapia, Oreochromis niloticus fingerlings
}

\author{
Ibiyo, L M. O.', Atteh, J. O. ${ }^{2}$, Omotosho J. S. ${ }^{3}$ and Madu C. T.' \\ 'National Institute for Freshwater Fisheries Research, \\ P.M.B. 6006, New Bussa, Niger State, Nigeria. \\ ${ }^{2}$ Department of Animal Production, University of torin, P.M.B. 1515, llorin, Nigeria. \\ ${ }^{3}$ Department of Zoology, University of Ilorin, P.M.B. 1515, Ilorin, Nigeria. \\ Correspondence Author:-email: oniviemercy@yahoo.com
}

\begin{abstract}
Sixteen (16) weeks feeding trial in a randomized design with three replicates was conducted to study the response of 180 Oreochromis niloticus fingerlings to borolab pulpas a source of vitamin $C$. They were fed a basal diet without supplemental vitamin $C$ in the first 2 weeks of conditioning to deplete some stored ascorbate. Diets supplemented with $1008 \mathrm{mg}$ ascorbyl-2-monophosphate $\mathrm{Mg}^{2+}$ (AMP) $\mathrm{kg}^{-1}$ diet (diet 1 ); $84 \mathrm{~g}$ baobab pulp $\mathrm{kg}^{-1}$ (diet 2) and $168 \mathrm{~g}$ baobab pulp $\mathrm{kg}^{-1}$ diet (diet 3) were evaluated. There was no significant difference $(P>0.05)$ in terms of weight gain, feed efficiency ratio, protein efficiency ratio, specific growth rate and survival between the groups fed diets 1 and 3 . There was a significant difference between the groups fed diet 2 and either of the other diets. Total ascorbate concentration of the liver was significantly $(P<0.05)$ higher in the groups fed diet 3. The crude protein content of the final fish was significantly $(P<0.05)$ higher in the groups fed diet supplemented with AMP. Interestingly none of the groups exhibited the characteristic symptoms of vitamin $C$ deficiency. The results of this experiment suggest that Oreochromis niloticus was able to oblain vitamin $C$ from the baobab pulp and tend to recommend baobab pulp at a level not less than $168 \mathrm{~g} \mathrm{~kg}$ 'diet in the nutrition of Oreochromis niloticus based on the condition of this study.
\end{abstract}

Key words: Baobab pulp, vitamin C, deit, Oreochromis niloticus

\section{INTRODUCTION}

Vitamin C has been identified as essential nutrient in most fish nutrition (Dabrowski 1990, Fracalossi et al., 2001). Soliman et al., (1994), reported a requirement value of $42 \mathrm{mg}$ of vitamin $\mathrm{C} / 100 \mathrm{~g}$ of diet for Nile tilapia, while NRC (1993) recommended $50 \mathrm{mg}$ vitamin C $/ \mathrm{kg}$ for blue tilapia, Oreochromis curreus. Nile tilapia (Oreochromis niloticus) is widely cultured in the tropics (Balarin and Hatton, 1979) and is one of the most valuable fish species in Nigeria, particularly in a polyculture system with catfish. Tilapia species are useful in enhancing total harvest in aquaculture practices involving polyculture. Thus is made possible by its highly prolific nature. The fry and fingerlings serves as live food for the catfish while controlling the population of tilapia. Middendorp (1995) described the catfish as a "police-fish" in tilapia pond management. The important contribution of tilapia to the overall protein sources in Nigeria cannot be over emphasized.

In most studies involving vitamin C, the synthetic sources were used. In an on-farm condition (under a local farming environment), synthetic sources may be limiting owing to non-availability therefore natural sources could be of importance. Vitamin $\mathrm{C}$ tends to be stable in the natural ingredient than the poorly stored synthetic analogues. This stability tendency could be exploited as remedy for the poor handling that characterized fish feed processing. Baobab (Adansonia digitata) is an abundant plant in the savannah of tropical Africa. Its leave is a delicacy in the nutrition of most human in the savannah zone of Nigeria. The vitamin content of the baobab leaves has been noted for contribution to a healthy diet (Sidibe et al., 1998). The fruit is a rich source of vitamin C (Anon 1975; Sidibe et al., 1998). The herbivorous nature of tilapia could possibly afford it an ability to utilize the pulp of baobab fruits for vitamin $\mathrm{C}$ source. Information in this regard is scarce. This study was designed to examine the growth response of Nile tilapia fed diets supplemented with baobab pulp :ompared to a synthetic stable form; ascorbyl-2-monophosphate $\mathrm{Mg}^{2+}$ (AMP).

\section{Materials and Methods}

One hund ed and eighty (180) fingerlings of domesticated Nile tilapia (Oreochromis niloticus) with mean init al in of $1.1 \mathrm{~g}$ obtained from NIFFR hatchery was used for 16 weeks feeding trial in a completely ran tomize des gn. The fingerlings were fed a basal diet with $32.5 \%$ crude protein [an average of the 30 
35\% C.P range given by Jauncey and Ross, (1982) cited by NRC, 1993] (Table 1) without supplemental vitamin $\mathrm{C}$ in the first 2 weeks of conditioning in order to deplete some of the stored ascorbate. Three diets were evaluated; diet 1 (control) supplemented with $1008 \mathrm{mg}$ ascorbyl-2-monophosphate $\mathrm{Mg}^{2+}(\mathrm{AMP}) \mathrm{kg}^{-1}$ diet; diet 2 and 3 supplemented with $84 \mathrm{~g}$ and $168 \mathrm{~g}$ baobab pulp kg $\mathrm{kg}^{-1}$ diet respectively. These quantities of AMP (S. D. America, New York, NY) and baobab pulp (from the wild) has $420 \mathrm{mg}$ free ascorbic acid respectively except diet 2 with half of that (requirement level of $42 \mathrm{mg}$ ascorbic acid $100 \mathrm{~g}^{-1}$ diet; Soliman et al., 1994). The half of the baobab equivalent to AMP (diet 2) is about 4 times the requirement level of $50 \mathrm{mg}$ vitamin $\mathrm{C} \mathrm{kg}^{-1}$ diet recommended for blue tilapia, Oreochromis aureus (NRC, 1993). Diet 2 was made to contain half of the requirement level for $O$. niloticus to see whether ascorbic acid in its natural form could help to reduce the predetermined level which seems high compared to $O$. aureus with the fish still performing optimally. Diet preparation and preservation was as previously described by Ibiyo et al., (2006). The study was conducted in a mini-flow through experimental system previously described by Madu (1989). The basal diet was stopped two days prior to the commencement of the study. At the start of the experiment 8 fish were sacrificed, excised, livers sampled and pooled for determining ascorbic acid status after acclimatization. The supplementation of the two forms of vitamin $\mathrm{C}$ was achieved by the replacement of the cellulose portion in the basal diet. Samples of the experimental diets were analyzed for vitamin $\mathrm{C}$ content after processing. Each treatment has triplicate tanks with 20 fish $\operatorname{tank}^{-1}$. The fish were fed at $5 \%$ body weight, divided and supplied at the hours of 008 and 1800 daily. Tanks were scrubbed at 2 days intervals despite flow through system in order to minimized microbial growth in the culture system that could possibly alter the results. Mortality and the health condition of the fish were also observed and recorded at such occasion. Fish weights were monitored at 2 weeks intervals and feeding rates were consequently adjusted.

At the end of the experimental period weights were taken. Three fish per group (a total of nine fish per dietary treatment) were killed for whole-body proximate analyses. Analyses of proximate compositions (crude protein, ash, and moisture) were performed by standard procedures (Association of Official Analytical Chemists, 2000). For the vitamin C analyses, five fish were randomly selected from each group (total of fifteen fish per dietary treatment) and killed to collect livers. Blood was obtained from the heart into sample bottles with EDTA by sacrificing the fish randomly selected from each group (total of fifteen fish per treatment). Ilaematocrit was determined by the microhaemotocrit method and haemoglobin (Hb) was determined using the cynomethaemoglobin method from the blood samples. Total ascorbate were analysed in liver samples by the dinitrophenylhydrazine colorimetric method with modifications for interfering substances (Dabrowski \& Hinterleitner, 1989).

The data obtained from the physical and analytical measurements were subjected to one way analysis of variance and all differences were considered significant at $P<0.05$. Where ANOVA identified significance difference, Student Newman-Keuls comparison test of one-way ANOVA was used to compare the mean differences by the SPSS statistical package (version 10.0; SPSS Inc., Chicago, IL).

\section{RESULTS}

The liver ascorbate concentration prior to fish subjection to the treatment was $38 \mathrm{~g} \mathrm{~g}^{-1}$. Baobab pulp analysis showed a concentration of $2.5 \mathrm{mg}$ vitamin $\mathrm{Cg}^{-1}$. The diet analysis after preparation showed $1.5-2 \%$ lost in vitamin $\mathrm{C}$ levels. The fish from the three treatments progressively increased their body weight. There was no significant difference $(P>0.05)$ in terms of weight gain, feed conversion ratio, protein efficiency ratio, specilic growth rate and survival between the groups fed diets supplemented with AMP (treatment 1) and baobab pulp equivalent to AMP ( $168 \mathrm{~g}$ of baobab pulp $\mathrm{kg}^{-1}$ diet; treatment 3$)$. However, there was a significant $(\mathrm{P}<0.05)$ difference between the groups supplemented with $84 \mathrm{~g}$ of baobab pulp kg-1 diet (treatment 2$)$ and either of the other treatments in terms of the foregoing parameters except survival (Table 2). There were variations in growth reflected in the cumulative weight of the fish due to the effect of the three treatments on the respective groups of fish (Figure 1). Total ascorbate concentration in the liver was significantly $(\mathrm{P}<0.05)$ higher in the groups subjected to treatment 3 (Table 3 ). The proximate composition analysis showed that crude protein content of the final fish was significantly $(\mathrm{P}<0.05)$ higher in the groups fed diet supplemented with AMP(Table 3). There was no significance difference; in terms of crude fat, crude fibre, ash and moisture content of the fish hence the data are not presented. Also, the hacmatological analysis showed that, the groups fed AMP was significantly $(\mathrm{P}<0.05)$ higher in terms of haematocrit but was not significantly $(\mathrm{P}>0.05)$ different from the group that were fed baobab equivalent to AMP with respect to haemoglobin content of the blood (Table 3). However there was significant difference $(\mathrm{P}<0.05)$ between the groups that were subjected to treatment 2 and 3 with respect to both parameters. None of the groups exhibited the characteristic symptoms of vitamin C deficiency. 


\section{DISCUSSION}

The increased body weight exhibited by all the groups revealed that the fish were able to obtain vitamin C for their body physiological functions (Figure 1). However there was distinct difference in growth between the $\Lambda M P$ and baobab equivalent compared to the group with half of such quantity (diet 2 ) with effect from the $4^{\text {th }}$ week of the experiment. The similar growth performance observed in the early' part of experimental period (Figure 1) might have resulted from the complementary effects of the tissue ascorbate reserves on the dietary ascorbic acid. The vitamin $\mathrm{C}$ concentration of the baobab pulp which was determined to be $2.5 \mathrm{mg}$ vitamin $\mathrm{C}$ $\mathrm{g}^{-1}$ of baobab pulp, suggest that baobab pulp contains substantial quantities of vitamin $\mathrm{C}$ as opposed to the trace quantity reported by FAO (1968). The difference might be associated to sophistication in method of determination. The significant poor weight gain, feed efficiency ratio and protein efficiency ratio showed by the groups fed half AMP baobab equivalent ( $84 \mathrm{~g}$ baobab pulp kg $\mathrm{kg}^{-1}$ diet) level, is an indication that the fish were not able to obtain an optimum required level of vitamin $\mathrm{C}$ from such quantity for their optimum body physiological functions. Though, it was able to sustain the fish as survival was nat affected and prevented occurrence of deficiency symptoms of vitamin C. Such was observed with a level of $50 \mathrm{mg} \mathrm{L}$-ascorbic acid $\mathrm{kg}^{-1}$ diet in Oreochromis niloticus (Soliman et al., 1994) and Heterobranchus longifilis (Ibiyo el al., 2006). This confirms that Nile tilapia require a substantially higher vitamin Q level compared to blue tilapia irrespective of the nature or form of vitamin C.

The significant higher crude protein content of the final fish of the AMP group tend to indicate ready availability of vitamin $\mathrm{C}$ in the synthetic form for use as a co-factor in protein metabolism of the fish. That notwithstanding, the vitamin $\mathrm{C}$ requirement for the release of iron ( $\mathrm{Fe}$ ) from transferrin and ferritin and its subsequent incorporation into haeme compound for haemoglobin synthesis (Wegger and Palludan, 1990) seems to be appropriately met irrespective of the form with respect to the groups fed diet 1 and 3 hence there was no significant difference between them in terms of haemoglobin content. The group with treatment 2 continually indicated an inadequate amount of vitamin $\mathrm{C}$ which also reflected in the haematological parameters, indicating that such level could not meet the need of the fish with respect to blood formation as vitamin C is essential in haemopoisis for the maturation of ery throcytes (Johnson et al, 1971 cited by Halver, 2005). This further confirms total dependency on dietary, exogenous sources of vitamin C in Oreochromis niloticus nutrition (Soliman et al., 1994). The no significance difference, in survival exhibited by fish from all the treatments is an indication that baobab pulp is an effective natural source of vitamin $\mathrm{C}$ and need to be exploited in this fish nutrition. Interestingly, there was no any observable characteristic symptom due to deficiency of vitamin $\mathrm{C}$ in any of the groups; still suggesting that Oreochromis niloticus was able to utilize the baobab pulp for vitamin $\mathrm{C}$ source. The results of this study tend to suggest the use of baobab pulp at at level not less than $168 \mathrm{~kg}^{-1}$ in the diet of Oreochromis niloticus as an alternative source of vitamin $\mathrm{C}$ in this fish nutrition.

References

Anon, L. K. (1975). Minutes of sensory evaluation Division Business meeting at $35^{\text {th }}$ Annual meeting of the Institute of Food Technologists, Chicago, June $10^{\text {th }}$.

Association of Official Analytical Chemists (A.O.A.C) (2000). $17^{\text {th }}$ Edition, A.O.A.C., Washington DC. Pg 21,447

Balarin, J. D. and Hatton J. P. (1979). Culture systems and methods of rearing tilapia in Africa. In Tilapia: a guide to their biology and culture in Africa, pp. 45 56. Institute of Aquaculture, University of Stirling, Scotland.

Dabrowski K. (1990). Absorption of ascorbic acid and ascorbic sulfate and ascorbate metabolism in common carp (Cyprinus carpio L.) Comp. Biochem. Physiol. 160: 549561.

Dabrowski K \& Hinterleitner S (1989). Simultaneous analysis of ascorbic acid, dehydroascorbic acid and ascorbic sulphate in biological materials. Analyst 114, 8387.

Food and Agriculture Organization (1968). Food Composition for use in A frica

Fracalossi DM, Allen ME, Yuyama LK, Oftedal OT. (2001). Ascorbic acid Biosynthesis in Amazonian fishes. Aquaculture 192, 321332.

Halver J. E. (2005): The 'vitamins. In: Halver J.E and Hardy R.W, editors. Fish Nitrition, $3^{\text {rd }}$ edition, Academic press, San Diego, CA, p 61-141.

Ibiyo, L. M. O., Madu C. T. and Eze S. S. (2006): Effects of vitamin C supplementation on the growth of Heterobranchus longifilis fingerlings. Archives of Animal Nutrition 60(4): $325-332$.

Jauncey, K. and Ross, B. (1982): A guide to Tilapia feeds and feeding:Institute of Aquaculture University of Sternling, Scotland, UK $111 \mathrm{pp}$. 
Madu, C. T. (1989). Hatchery Management and dietary protein utilization in the mudfish, Clarias gariepinus (L). Ph.D. Thesis. University of Jos, Nigeria. $218 \mathrm{pp}$.

McCay PB (1985). Vitamin E: Interactions with free radicals and ascorbate. Annual Review of Nutrition 5, 323340 .

Middendorp, A. J. (1995). Pond farming of Nile Tilapia, Oreochromis niloticus in northern Cameroon. Feeding combinations of cottonseed cake and brewery waste in fingerling culture, hand-sexed male monosex culture and mixed culture with police-fish, Clarias gariepinus (Burchell). Aquaculture Research 26.715722 .

NRC (National Research Council) (1993). Nutrient requirements of Fish. National Academy Press, Washington, DC.pp. 114

Sidibe M., Scheuring, J. F., Kone-M, Schierle J., Frigg, M. and Hofman, P. (1998). The baobab tree as a source of vitamins. In Agroforestry Today 10:4, 7-9

Soliman, A. K., K. Jauncey and R. J. Roberts, (1994). Water-soluble vitamin requirements of tilapia: ascorbic acid (vitamin C) requirement of Nile tilapia, Oreochromis niloticus (L.). Aquaculture 2 .". Fisheries . Management 25, 269-278.

Tappel AL (1968). Will antioxidant nutrients slow aging processes? Geriatrics 23, 97105.

Wegger, I., Palludan, B., (1990). Iron, zinc and copper status of ascorbic acid deficient boars. In: Wenk, C.,

Fenster, R., Volker, L. Eds. , Ascorbic Acid in Domestic Animals. Proceedings of the 2nd Symposium, 9th12th Oct, Kartause, Ittingen, Switzerland, pp. 114122.

\begin{tabular}{|c|c|}
\hline Ingredients & Inclusion level \\
\hline Fish meal & 15.00 \\
\hline Soybean meal $=$ & 20.00 \\
\hline Groundnut cake & 26.05 \\
\hline Maize bran & 6.25 \\
\hline Rice bran & 5.00 \\
\hline Starch & 2.00 \\
\hline Palm oil & 2.00 \\
\hline Bone meal & 2.00 \\
\hline Premix ${ }^{*}$ & 1.00 \\
\hline Cellulose & 18.00 \\
\hline Chromic oxide & 0.50 \\
\hline Methionine & 0.20 \\
\hline Total & 100.00 \\
\hline \multicolumn{2}{|l|}{ Proximate Composition } \\
\hline Crude protein $(\%)$ & 31.95 \\
\hline Crude fat $(\%)$ & 8.60 \\
\hline Crude fibre $(\%)$ & 7.35 \\
\hline Ash $(\%)$ & 8.30 \\
\hline NFF $(\%)$ & 36.6 \\
\hline Moisture content $(\%)$ & 7.20 \\
\hline
\end{tabular}

* Provides per kg diet: Vitamin A, $50000 \mathrm{IU}$, Vitamin D, $25000 \mathrm{IU}$, Vitamin E 160mg, Vitamin K 8mg; Vitamin $\mathrm{B}_{1}$ 12mg; Vitamin $B_{2} 22 \mathrm{mg}$; Vitamin $B_{6} 20 \mathrm{mg}$; Vitamin $B_{12} 220 \mathrm{mg}$; Biotin $4 \mathrm{mg}$; Zinc 320mg; lodine $6 \mathrm{mg}$; Calcium pantothenate $46 \mathrm{mg}$, Cupper $34 \mathrm{mg}$ Cobalt $1.2 \mathrm{mg}$; Selenium $0.48 \mathrm{mg}$; Antioxidant $480 \mathrm{mg}$; Choline chloride $0.1 \mathrm{mg}$ 
Table 2: $\quad$ Growth, feed utilization parameters and survival rate of O. niloticus fed diets supplemented with AMP and Baobab pulp $0 \quad 16$ weeks.

\begin{tabular}{|l|l|l|l|l|}
\hline \multicolumn{1}{|c|}{ Parameters } & Diet 1 & Diet 2 & Diet 3 & SE \\
\hline Final weight $\left(\mathrm{g} \mathrm{fish}^{-1}\right)$ & $18.17^{\mathrm{a}}$ & $15.10^{\mathrm{b}}$ & $17.97^{\mathrm{a}}$ & 0.146 \\
\hline Specific growth rate $\left(\%\right.$ day $\left.^{-1}\right)$ & $2.51^{\mathrm{a}}$ & $2.34^{\mathrm{b}}$ & $2.48^{\mathrm{a}}$ & 1.46 \\
\hline Feed conversion ratio & $1.25^{\mathrm{b}}$ & $1.39^{\mathrm{a}}$ & $1.27^{\mathrm{b}}$ & 1.15 \\
\hline Protcin efficiency ratio & $2.45^{\mathrm{a}}$ & $2.21^{\mathrm{b}}$ & $2.42^{\mathrm{a}}$ & 2.1 \\
\hline Survival & 93.8 & 93.8 & 94.0 & NS \\
\hline
\end{tabular}

a c Means in each row with different superscripts are significantly different $(\mathrm{P}<0.05)$.

Table 3: Blood parameters, liver ascorbate concentrations and proximate body composition of $\boldsymbol{O}$. niloticus fed diets supplemented with AMP and Baobab pulp

\begin{tabular}{|l|c|c|c|c|}
\hline \multicolumn{1}{|c|}{ Parameters } & Diet 1 & Diet 2 & Diet 3 & SE \\
\hline Haematocrit (\%) & $43.00^{\mathrm{a}}$ & $35.37^{\mathrm{c}}$ & $41.83^{\mathrm{b}}$ & 9.03 \\
\hline Haemoglobin $\left(\mathrm{g} \mathrm{dl}^{-1}\right)$ & $13.12^{\mathrm{a}}$ & $9.10^{\mathrm{b}}$ & $13.00^{\mathrm{a}}$ & 0.11 \\
\hline Liver ascorbate $\left(\mu \mathrm{g} \mathrm{g}^{-1}\right)$ & $91.43^{\mathrm{b}}$ & $52.67^{\mathrm{c}}$ & $94.13^{\mathrm{a}}$ & 0.31 \\
\hline Proximate body composition & $17.24^{\mathrm{a}}$ & $16.04^{\mathrm{c}}$ & $16.68^{\mathrm{b}}$ & 0.16 \\
\hline
\end{tabular}

a c Means in each row with different superscripts are significantly different $(\mathrm{P}<0.05)$. 


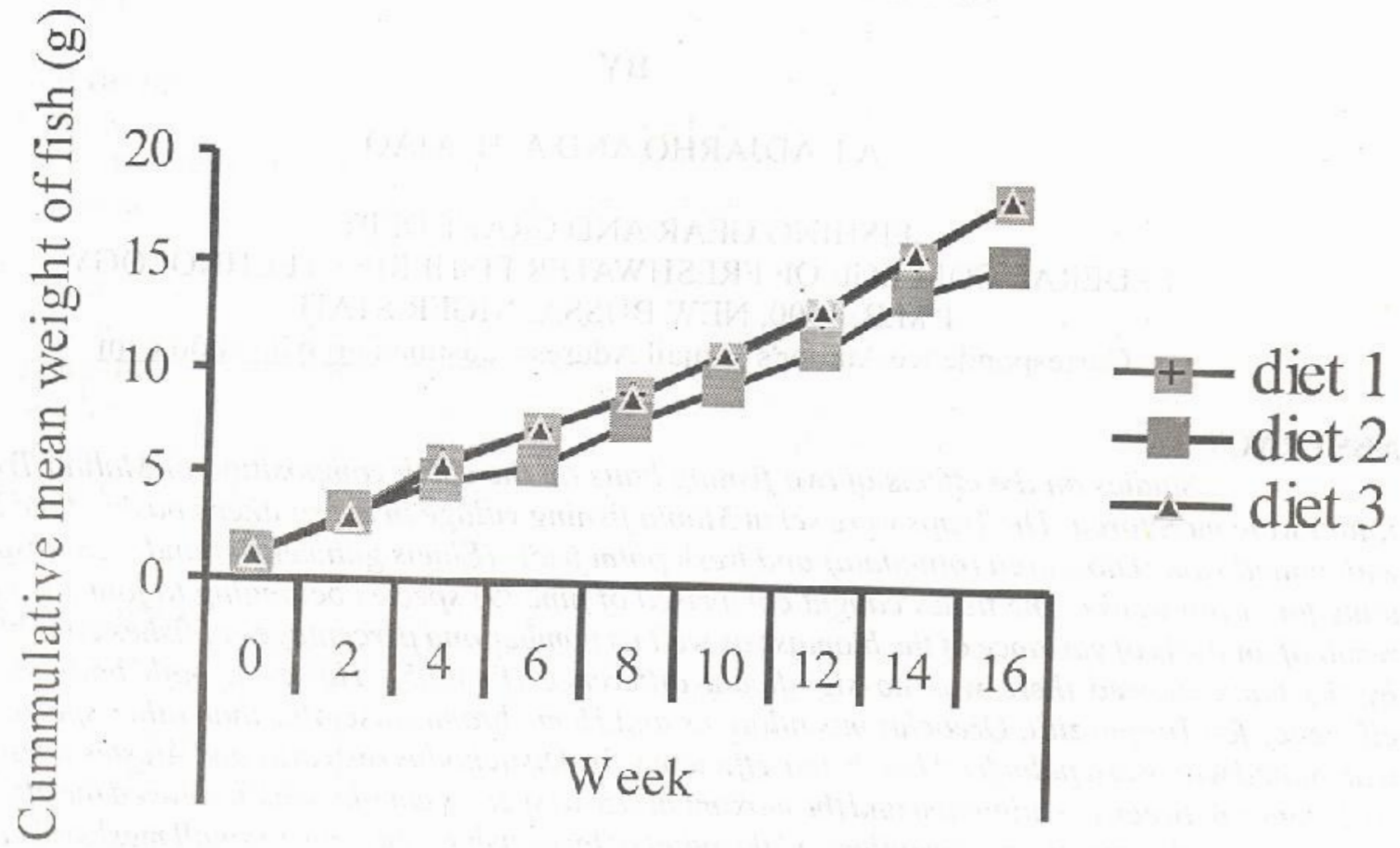

Figure 1: Effects of sources of vitamin $\mathrm{C}$ on the growth of 0 . niloticus $(0-16$ weeks). AMP (diet 1$)$,
$84 \mathrm{~g}$ baobab pulp kg-1 (diet 2$)$ and $160 \mathrm{~g}$ 